\title{
How farmers' non-agricultural employment affects rural land circulation in China?
}

\author{
WANG Jiayue ${ }^{1,2},{ }^{*}$ XIN Liangjie ${ }^{1}$, WANG Yahui ${ }^{3}$ \\ 1. Key Laboratory of Land Surface Pattern and Simulation, Institute of Geographic Sciences and Natural Re- \\ sources Research, CAS, Beijing 100101, China; \\ 2. University of Chinese Academy of Sciences, Beijing 100049, China; \\ 3. School of Geographical Science, Southwest University, Chongqing 400715, China
}

\begin{abstract}
To clarify the impact of non-agricultural employment on rural land circulation in China, we built logit models using the Chinese Household Income Project 2013 dataset, which includes 18,948 household samples over 15 provinces, 126 cities and 234 counties of China in 2013. We use the proportion of non-agricultural income, the proportion of non-agricultural laborers and non-agricultural fixed operating assets to reflect the degree of the households' dependence on agriculture, the degree of the households' laborers committed to non-agricultural employment and the stability of non-agricultural employment, respectively. The results show that the stability of non-agricultural employment is an important reason for farmers to transfer out their land, and an increase in non-agricultural income is the fundamental reason. The proportion of non-agricultural assets has the greatest impact on the decision to transfer land, followed by the proportion of non-agricultural income. Per unit increase in the non-agricultural income ratio has a stronger effect on the transfer-out decision than it does on the transfer-in decision, which is a 0.09 increase of the probability of transfer-out the land and a 0.07 decrease of the probability of transfer-in the land. In terms of regional differences, when considering the impact of non-agricultural employment on the land transfer-out decision, the impacts of non-agricultural income and labor force are the greatest in the Central region. The impact of non-agricultural assets is the greatest in the Eastern region. For the Eastern region, the decision to transfer out land is mainly affected by non-agricultural assets and the non-agricultural labor force, and the decision to transfer in land is mainly affected by non-agricultural assets. In the Central and Western regions, the decision to transfer out land is mainly affected by non-agricultural assets, non-agricultural income and the non-agricultural labor force, in that order. The decision to transfer in land in the Central region is not significantly affected by non-agricultural employment. The decision to transfer in land in the Western region is mainly affected by non-agricultural assets, non-agricultural labor force and non-agricultural income, in that order. We note that non-agricultural assets have a prominent impact on land transfer, which shows that the stability of non-agricultural employment has an important impact on land transfer decision-making. Vocational training for rural labor forces may be an effective means to promote
\end{abstract}

Received: 2019-01-09 Accepted: 2019-06-05

Foundation: National Natural Science Foundation of China, No.41571095; National Key Basic Research Program of China, No.2015CB452702

Author: Wang Jiayue, PhD Candidate, specialized in land use change and its effects. E-mail: wangjy.16b@igsnrr.ac.cn

*Corresponding author: Xin Liangjie, Associate Professor, specialized in land use change and its effects. E-mail: xinlj@igsnrr.ac.cn 
stable non-agricultural employment and simultaneously facilitate rural land circulation, especially in Central and Western China.

Keywords: farmers' non-agricultural employment; rural land circulation; moderate scale management; China; CHIP2013 dataset

\section{Introduction}

In the late 1970s and early 1980s, the Household Contract Responsibility System (HCRS) replaced the People's Commune System, and small-scale household production became the fundamental system underlying China's agriculture. In that era, China's household registration system restricted the transfer of the surplus agricultural labor force, and so household income maximization could only be achieved through the maximization of land output (Zhu et al., 2007). As a result, rural households input more labor and other materials into agricultural production, and China's agriculture was dramatically revived. It is estimated that the HCRS contributed approximately $48.69 \%$ to the growth of agricultural production from 1978 to 1984 in China (Lin, 1992).

Although the HCRS was highly successful, it also resulted in tiny and fragmented farms. According to HCRS, village collective land was equally distributed to every villager. Given the abundant population and limited collective land, the land allotted to each family was very limited. Moreover, agricultural land differed from parcel to parcel in terms of location and fertility. Thus, the total land holding of each family was not only small but also fragmented and scattered (Ma et al., 2015). A national survey of the Fixed Rural Observation Villages system approved by the CPC Central Committee Secretariat indicated that in 1986, the average cultivated area per household in China was only $0.61 \mathrm{ha}(9.2 \mathrm{mu})$ but fragmented into 8.4 plots, each averaging only $0.07 \mathrm{ha} \mathrm{(1.1} \mathrm{mu)} \mathrm{(OFROV,} \mathrm{2001).}$

This fragmented structure of family farming remained largely unchanged and unchallenged until now. The Fixed Rural Observation Villages system showed that in 2009, the average cultivated area per household was $0.47 \mathrm{ha}(7.12 \mathrm{mu})$ and was fragmented into 4.1 plots. Each plot averaged only 0.11 ha (1.7 mu) (OFROV, 2010).

Although fragmentation may have beneficial effects by reducing risk through the spatial dispersion of plots and crop diversity (Kawasaki, 2010; Manjunatha et al., 2013) and by allowing higher land productivity (Niroula and Thapa, 2007), the negative effects of land fragmentation are more noticeable than the positive ones. Many studies have shown that small land parcels impede the application of new technologies and production models (Tan et al., 2003) as well as the efficient use of labor and machines (Todorova and Lulcheva, 2006). Land fragmentation also makes large-scale farming and irrigation management difficult (Penov, 2004). Moreover, abundant ridges of scattered tiny parcels increase the ineffective land area (Tan et al., 2003).

For small rural farmers, scattered tiny parcels increase not only fuel inputs and labor hours for commuting but also the application of fertilizers and pesticides, most likely due to the substitution effects from labor (Kawasaki, 2011; Manjunatha et al., 2013). Meanwhile, little agricultural production surplus seriously restricts the increases of labor productivity and agricultural income, and such a system cannot withstand natural disaster risk and market volatility risk. It is very difficult for small farms to compete with international large-scale farms and to provide high enough income levels to attract young, well-educated farmers 
(Pilgaard and Birch, 2013; Cassidy and Mcgrath, 2015).

China's central government noted the shortcomings of land fragmentation as early as the initial stage of the reform and opening-up. The Chinese No 1 Central Document early in 1984 encouraged land transfer. Opinions issued by the General Office of the CPC Central Committee and the General Office of the State Council in November 2014 on speeding up the circulation of rural land management rights in an orderly fashion and developing optimum scale management indicated that farmers with a land area equivalent to 10 to 15 times the local average and agricultural income equivalent to local nonfarm income should be given priority support. The Chinese No 1 Central Document of 2015 reiterated that the government would guide the orderly circulation of rural land management rights and encourage the development of optimum-scale family farms.

Although the government encourages land circulation and optimum-scale management, the land rental market is only just beginning in China, and it varies greatly by region (Qian and Mou, 2012). The Second National Agricultural Census conducted by the Chinese Ministry of Agriculture indicated that, in 2006, the total area of land circulation accounted for $10.8 \%$ of the national total. The number of farmers renting land accounted for $8.2 \%$ of the national total, and the number of farmers renting out land accounted for $6.9 \%$. Many scholars have also confirmed that China's land rental market is developing slowly (Bao et al., 2009; Gao and Huang, 2011; Tan et al., 2013), and land rental arrangements are generally informal, short term and arranged between households living in the same village (Feng et al., 2010). These problems are more prevalent in economically less developed regions.

From a macro perspective, land circulation concerns the future of agriculture and even affects the food security and social stability of China; from a micro perspective, land circulation changes farmers' livelihoods and might produce landless or poor farmers.

Many scholars have conducted empirical research on the driving forces of China's land rental market from different perspectives (Yang, 2000; Kung and Lee, 2001; Huang et al., 2012; Che, 2014; Yan and Huo, 2016) and found that there are many factors that affect rural land circulation, such as heterogeneity in agricultural productivity (Yang, 2000; Chen et al., 2014), land property rights (Huang and Wang, 2008; Liu and $\mathrm{Xu}, 2016$ ), the degree of land fragmentation and related transaction costs (Liu et al., 2008; Huy et al., 2016). However, most studies agree that the nonfarmer labor market is the main catalyst in the development of the land rental market (Yang, 2000; Kung and Lee, 2001; Huang et al., 2012). As to whether non-agricultural employment will inevitably lead to land transfer, some studies believe that the answer is yes. Kung's study showed that the start of the land rental market in China is temporally consistent with the accelerating development of the nonfarmer labor market (Kung and Lee, 2001). Rural household survey data also show that nonfarm employment and nonfarm income are the main factors influencing land leasing (Feng, 2008; Han and Zhong, 2011). Deininger's study indicated that an increase in farmers' non-agricultural employment opportunities would reduce the possibility of renting land and increase the opportunities for farmers leasing land (Deininger and Jin, 2005). However, some studies believe that non-agricultural employment does not necessarily lead to land transfer because of the intergenerational division of labor, gender division of labor and substitution between labor, capital and technology (Jia, 2012). It is believed that there is no stable relationship between these factors in the short run, but in the long run, they are mutually reinforcing (Xu and Guo, 2011). The impact of non-agricultural employment on land trans- 
fer may also be affected by other factors, and previous studies also investigate the impact of the interaction between other factors and non-agricultural employment on land transfer. Land fragmentation strengthens the effect of non-agricultural labor supply on agricultural land outflow (Xie and Lu, 2017).

Previous studies have provided us with a useful understanding of the rural land transfer problem in China. Unfortunately, two main shortcomings exist. (1) Studies are often limited to small geographic areas. At present, there are obvious regional differences in the development of China's land transfer market, and a nationwide study is required to reflect regional differences. At a global level, a nationwide study of China will also enlighten the development of land rental markets in Ethiopia (Deininger et al., 2001) and other developing countries. (2) The existing literature is focused more on whether land is circulating and pays less attention to the direction of land circulation, i.e., renting in or renting out. If we do not know the differences between the two types of farmers, the effectiveness of land circulation policies may be greatly reduced. (3) The utilized measurement indicators of non-agricultural employment are different in different studies. The stability of non-agricultural employment is also an important factor affecting the decision-making around land transfer. Therefore, this study chooses not only the proportion of household non-agricultural income and of the household non-agricultural labor force but also the proportion of non-agricultural assets to represent the stability of non-agricultural employment and comprehensively reflect the impact of non-agricultural employment on rural land circulation.

The overall goal of this paper is to explore the impact of off-farm employment on the rural land rental market. To be nationally representative, the data of the 2014 Chinese Household Income Project Survey were used in this paper. The framework of the paper is organized as follows. The second section offers the theoretical framework and analysis of this study; the third section describes the dataset and defines the variables of the study; the fourth and fifth sections develop econometric models and analyze the impact of off-farm income on land circulation; and the final section presents the conclusions of this study.

\section{Methodology}

\subsection{Mechanism of farmers' non-agricultural income to rural land circulation}

The most important factor in measuring non-agricultural employment is non-agricultural income, and there is a positive feedback loop between farmers' non-agricultural income and rural land circulation (Wang and Yang, 2011). Problems of labor force allocation in rural areas between agricultural and non-agricultural industries have arisen in conjunction with China's rapid economic development (Choi, 2001; Huang et al., 2009). The allocation of the rural labor force will change the allocation of rural land resources. When non-agricultural income has a comparative advantage compared to agricultural income, the opportunity cost of the agricultural labor force will be high (Chen et al., 2010; Hao et al., 2017). When this situation occurs, farmers reduce their farming time and even become migrant workers (Tian et al., 2009; Zhang et al., 2017). Accordingly, shortages in the agricultural labor force then become a fatal problem in agricultural management. Farmers pursue the maximization of the total household income, which compels them to reduce their productive farmland area. Behaviors such as out transfer and even abandonment of farmland in these households further 
decrease agricultural income, which leads to a rise in the proportion of non-agricultural income. This phenomenon is a positive feedback process from the rural land circulation perspective, as the households receiving more benefits from non-agricultural industry are more likely to rent out their land, and the more land they rent out, the greater their share of non-agricultural income will be in their total household income. Conversely, the higher the income farmers can earn from the agricultural industry in comparison with non-agricultural industry, the more willing they will be to cultivate more farmland (Figure 1).

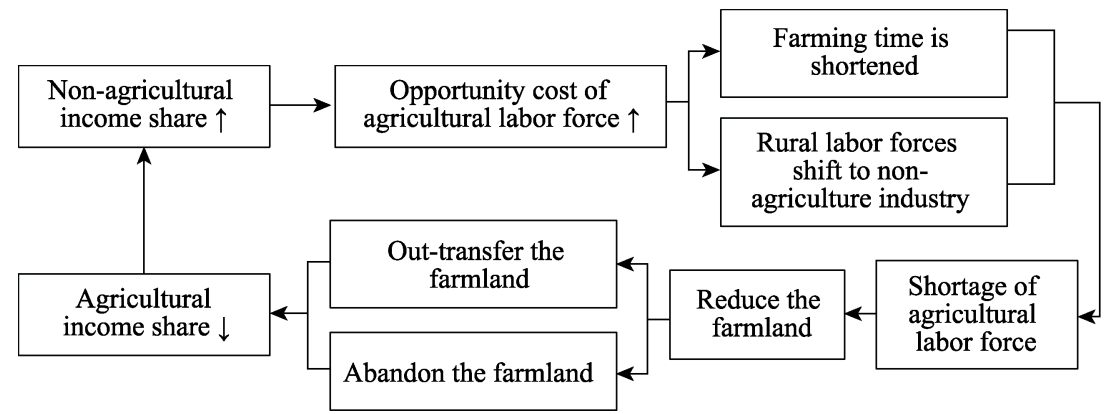

Figure 1 Positive feedback process between farmers' non-agricultural income and rural land circulation

According to agricultural household models (Singh et al., 1986), farmers' production and management decisions all aim to maximize household utility, which is determined by optimized production and optimized consumption. Production and consumption are affected by the allocation of the labor force and of farmland. Farmers will allocate their labor to agricultural and non-agricultural industries based on the comparative income offered by each of the two industries. Furthermore, the farmland allocation will change, and rural land circulation will appear.

Based on the theory of household economics and agricultural household models (Low, 1986; Ellis, 2006), this study builds a theory of labor force allocation based on the comparative advantage of non-agricultural income. The following are the three basic hypotheses.

(1) Laborers can choose to dedicate themselves to agricultural or non-agricultural industries without restriction. Initially, the limiting factor of age for the labor force is not considered, and later, the age of the labor force is added to the empirical model as a control variable.

(2) With a decrease in the number of household farming laborers, farmers tend to rent out their farmland. That is, the farmland that can be cultivated is used for unit labor. Initially, the agro-mechanization level and agricultural hired laborers are omitted, and subsequently, these two variables are added to the empirical model as control variables.

(3) Rural land contractual management rights can be transferred freely among households. Farmers can rent out their farmland once they are no longer willing to farm, and those who are willing to farm can lease more farmland for cultivation.

Figure 2 illustrates different household labor force allocations under the pursuit of total household income maximization. The horizontal axis shows the number of farming laborers, and the vertical axis represents the number of nonfarming laborers. We assume that the total number of household laborers is fixed. In this case, the labor force allocation is restricted by the line LL'; the different labor allocation schemes all fall on this line. We assume that $\mathrm{P}$ ' is the average agricultural income per capita and $\mathrm{P}$ is the average non-agricultural income per capita. Then, the total household income can be calculated by Equation (1); the income lines 
are a series of lines parallel to $I_{n}$ when $P^{\prime}$ is higher than $\mathrm{P}$, while the income lines are a series of lines parallel to $I_{n}^{\prime}$ when $\mathrm{P}$ is higher than P'. Rational farmers will choose the laborer allocation scheme that maximizes total household income. The optimal household income line is $I_{\max }^{\prime}$ when a family member can earn a greater per capita average income from agriculture, and the total labor force will be engaged in farming under these circumstances. Similarly, household labor will turn to non-agricultural industries once the average per capita income from migrant work is greater than that of farming.

When the per capita non-agricultural in-

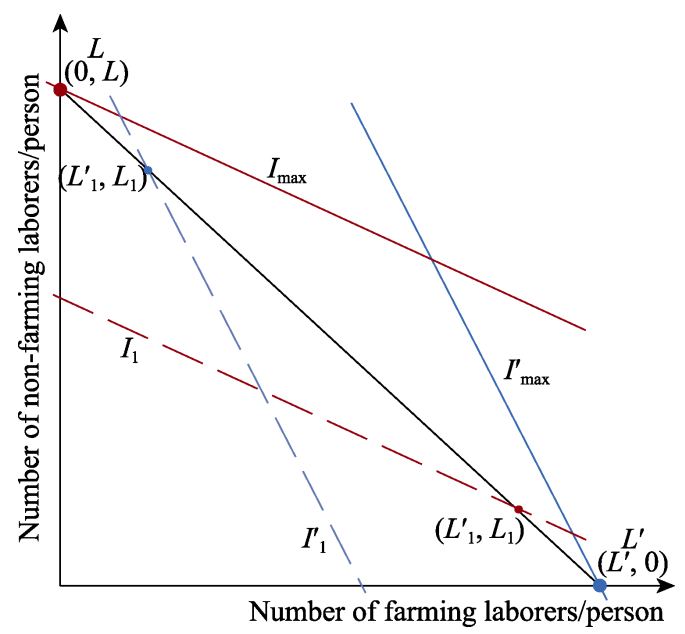

Figure 2 Labor force allocations under the pursuit of total household income maximization come is higher than that of agricultural income, non-agricultural income accounts for a greater proportion of the total household income, according to hypothesis 1 . The lack of a household labor force leads to inefficient cultivation following hypothesis 2 . Farmers must determine whether they want more farmland to cultivate, and then rural land circulation appears, according to hypothesis 3 . This process is consistent with the mechanism of farmers' non-agricultural income on rural land circulation, mentioned above.

$$
\begin{aligned}
& \text { Maximization of total household income }=\mathrm{L}^{\prime} \times \mathrm{P}^{\prime}+\mathrm{L} \times \mathrm{P}=\left\{\begin{array}{l}
\mathrm{I}^{\prime}, P^{\prime}>\mathrm{P} \\
\mathrm{I}, P^{\prime}<\mathrm{P}
\end{array} \quad\right. \text { s.t. } \\
& \mathrm{L}^{\prime}+\mathrm{L}=\text { constant } \mathrm{L}^{\prime}, \mathrm{L}, \mathrm{P}^{\prime}, \mathrm{P} \geqslant 0
\end{aligned}
$$

Based on the theoretical inference above, the following two main contentions are proposed. (1) Households whose income is mainly made up of non-agricultural income tend to transfer out rural land, while households whose income comes mainly from farming tend to rent more farmland to expand the scale of their agricultural production. (2) Rural land circulation is caused indirectly by labor force allocation, and the fundamental cause is the more obvious comparative advantage of non-agricultural income over agricultural income, which causes a decline in the importance of land in household income.

\subsection{Model selection}

The dependent variable is whether a household transfers its farmland. Because this variable is a categorical dichotomous variable, it is inappropriate to use a general linear regression model. To assess the impact of farmers' non-agricultural employment on rural land circulation, we choose a discrete choice model in consideration of the binary value of land circulation activities. A logit model was selected for our study to analyze the rural land circulation decision-making behavior of farmers. The functional form of the logit model is as follows:

$$
\begin{gathered}
\mathrm{P}\left(\text { rent_in }_{i}=1\right)=\frac{\exp \left(\alpha \mathrm{NON}-\mathrm{AGRI}-\mathrm{EMPLOYMENT}_{i}+\beta \mathrm{CONTROL}_{i}\right)}{1+\exp \left(\alpha \mathrm{NON}-\mathrm{AGRI}-\mathrm{EMPLOYMENT}_{i}+\beta \mathrm{CONTROL}_{i}\right)} \\
\mathrm{P}\left(\text { rent_out }_{i}=1\right)=\frac{\exp \left(\alpha \mathrm{NON}-\mathrm{AGRI}-\mathrm{EMPLOYMENT}_{i}+\beta \mathrm{CONTROL}_{i}\right)}{1+\exp \left(\alpha \mathrm{NON}-\mathrm{AGRI}_{-}-\mathrm{EMPLOYMENT}_{i}+\beta_{\mathrm{CONTROL}}\right)}
\end{gathered}
$$


The equations above show the farmland in-transfer logit model and out-transfer logit model, respectively. NON-AGRI-EMPLOYMENT $i$ are the key explanatory variables associated with non-agricultural employment and are the focus of this analysis. The $\mathrm{CONTROL}_{i}$ are a series of control variables, which mainly include householder characteristics, household characteristics, farmland management conditions and landform factors. The coefficients $\alpha$ and $\beta$ are parameters that need to be estimated.

\section{Data}

\subsection{Data specification}

The data used in this study come from the Chinese Household Income Project 2013, also known as CHIP2013 dataset. These data were the results from the fifth-round investigation of nationwide income and expenditure information conducted by the CHIP team in 2014, which mainly collected information on income and expenditures for 2013, with the help of the National Natural Science Foundation of China and the National Bureau of Statistics of China. The CHIP team selected 18,948 household samples covering 15 provinces, 126 cities and 234 counties based on a stratified systematic sampling method in Eastern, Central and Western China. A total of 11,013 samples covering rural households in 14 provinces were available for this study. The data contain household characteristics, information on household members, household income and asset information, and land and agricultural management information, among other information.

We eliminated the household samples without farmland and with uncertain and vacant values, resulting in 5,450 effective household samples in our study. Figure 3 shows the distribution of household samples in different provinces.

Western China (Total sample size: 1141 )

Central China (Total sample size: 2352)

Eastern China (Total sample size: 1957)
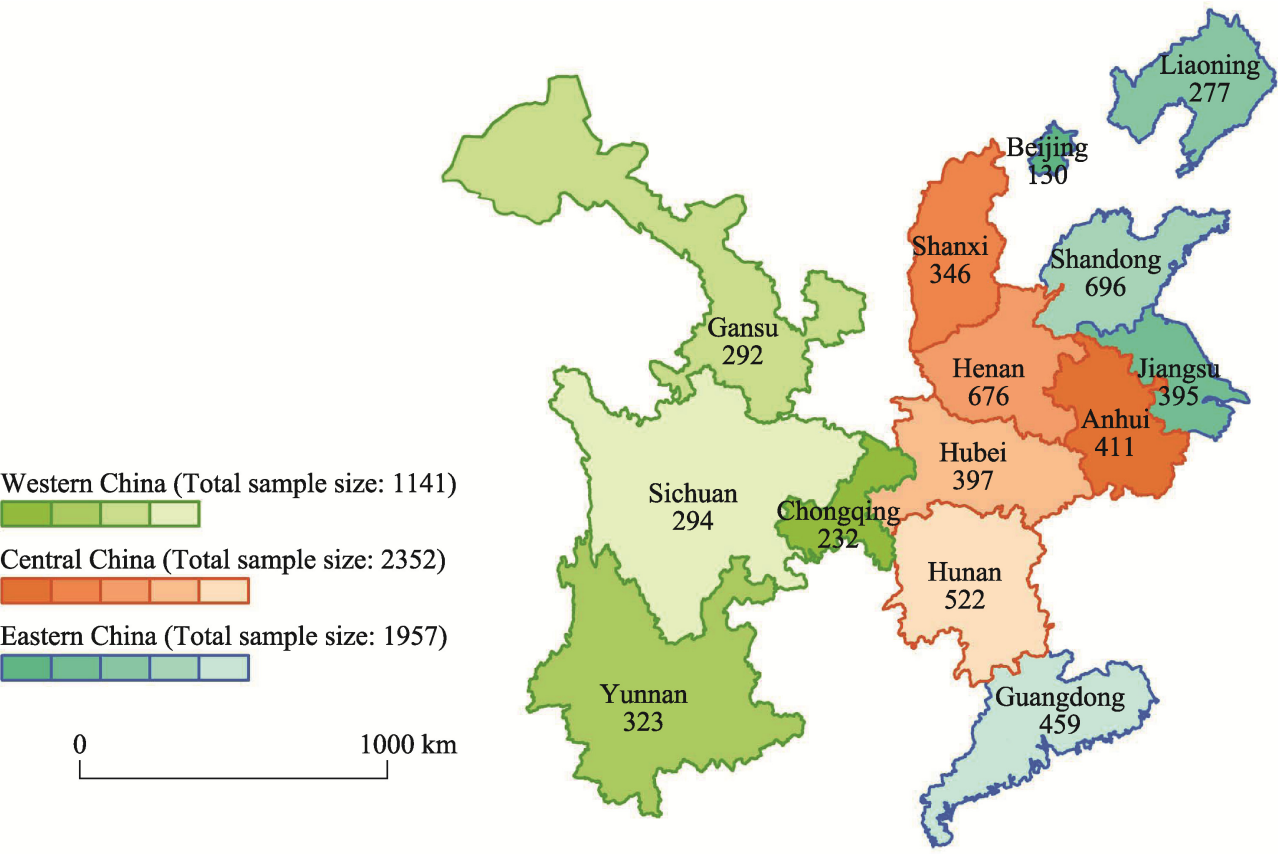

Figure 3 Household sample distribution in China (Total sample size $=5450$ ) 


\subsection{Variable selection and statistical description}

Based on the mechanism analysis, we selected the variables listed in Table 1 for the analysis of the impact of farmers' non-agricultural employment on rural land circulation. We built two models for land transfer-out and land transfer-in behaviors. The proportion of non-agricultural income, proportion of non-agricultural laborers and non-agricultural fixed operating assets are the core explanatory variables. These three variables reflect the degree of the households' dependence on agriculture, the degree of the households' laborers committed to non-agricultural employment and the stability of non-agricultural employment, respectively. The definition of the non-agricultural labor force in this study is a laborer who is engaged in non-agricultural employment in 2013.

Table 1 Variable definition and statistical description

\begin{tabular}{|c|c|c|c|c|c|c|c|}
\hline Type & Variable & Definition & Mean & $\begin{array}{l}\text { Standard } \\
\text { deviation }\end{array}$ & Min & Max & $\begin{array}{l}\text { Sample } \\
\text { size }\end{array}$ \\
\hline \multirow{2}{*}{$\begin{array}{l}\text { Rural land circu- } \\
\text { lation }\end{array}$} & transfer_out & $\begin{array}{l}\text { Land transfer-out } \\
(\mathrm{Yes}=1 ; \mathrm{No}=0)\end{array}$ & 0.21 & 0.41 & 0 & 1 & 5450 \\
\hline & transfer_in & $\begin{array}{l}\text { Land transfer-in }\left(\mathrm{Yes}_{\mathrm{e}}=1\right. \\
\mathrm{No}=0)\end{array}$ & 0.31 & 0.46 & 0 & 1 & 2536 \\
\hline \multirow{3}{*}{$\begin{array}{l}\text { Non-agricultural } \\
\text { employment }\end{array}$} & naincome_ratio & $\begin{array}{l}\text { Proportion of } \\
\text { non-agricultural income }\end{array}$ & 0.57 & 0.37 & 0 & 1 & 5450 \\
\hline & nalabor_ratio & $\begin{array}{l}\text { Proportion of } \\
\text { non-agricultural laborers }\end{array}$ & 0.20 & 0.26 & 0 & 1 & 5450 \\
\hline & naasset_ratio & $\begin{array}{l}\text { Proportion of } \\
\text { non-agricultural fixed } \\
\text { operating assets }\end{array}$ & 0.45 & 0.11 & 0.28 & 0.75 & 5450 \\
\hline \multirow{2}{*}{$\begin{array}{l}\text { Householders' } \\
\text { characteristics }\end{array}$} & education & $\begin{array}{l}\text { Education level (lowest } \\
\text { level }=1 \rightarrow \text { highest lev- } \\
\text { el=8) }\end{array}$ & 2.73 & 0.91 & 1 & 8 & 5416 \\
\hline & marriage & $\begin{array}{l}\text { Marital status (unmar- } \\
\text { ried }=1 \text {; married or has } \\
\text { been married }=0 \text { ) }\end{array}$ & 0.01 & 0.11 & 0 & 1 & 5450 \\
\hline \multirow{4}{*}{$\begin{array}{l}\text { Households' } \\
\text { characteristics }\end{array}$} & aver_age & $\begin{array}{l}\text { Average age of house- } \\
\text { hold labor }\end{array}$ & 46.00 & 11.87 & 21.5 & 93 & 5450 \\
\hline & cadre & $\begin{array}{l}\text { Village cadres in house- } \\
\text { holds }(\mathrm{Yes}=1 ; \mathrm{No}=0)\end{array}$ & 0.06 & 0.23 & 0 & 1 & 5434 \\
\hline & forest & $\begin{array}{l}\text { Grain for Green Project } \\
(\mathrm{Yes}=1 ; \mathrm{No}=0)\end{array}$ & 0.12 & 0.33 & 0 & 1 & 5450 \\
\hline & organization & $\begin{array}{l}\text { Agricultural cooperative } \\
\text { economic organization } \\
(\mathrm{Yes}=1 ; \mathrm{No}=0)\end{array}$ & 0.03 & 0.18 & 0 & 1 & 5450 \\
\hline $\begin{array}{l}\text { Households' } \\
\text { characteristics }\end{array}$ & requisition & $\begin{array}{l}\text { Land requisition }(\mathrm{Yes}=1 ; \\
\mathrm{No}=0)\end{array}$ & 0.10 & 0.30 & 0 & 1 & 5450 \\
\hline $\begin{array}{l}\text { Land manage- } \\
\text { ment }\end{array}$ & pcland & $\begin{array}{l}\text { Per capita area of farm- } \\
\text { land (mu/person) }(1 \\
m u=1 / 15 \text { ha) }\end{array}$ & 1.89 & 2.16 & 0.08 & 12.5 & 5450 \\
\hline Economic level & pcgdp & $\begin{array}{l}\text { The logarithm values of } \\
\text { per capita GDP of prov- } \\
\text { inces (yuan/person) }\end{array}$ & 10.65 & 0.34 & 10.10 & 11.44 & 5450 \\
\hline \multirow[t]{2}{*}{$\begin{array}{l}\text { Landform condi- } \\
\text { tion }\end{array}$} & landforms & $\begin{array}{l}\text { Landforms (plain }=1 ; \\
\text { mountainous area }=0 \text { ) }\end{array}$ & 0.56 & 0.50 & 0 & 1 & 5450 \\
\hline & east & $\begin{array}{l}\text { Eastern China }=1 \text {; other } \\
\text { areas }=0\end{array}$ & 0.36 & 0.48 & 0 & 1 & 5450 \\
\hline \multirow[t]{2}{*}{$\begin{array}{l}\text { Regional dummy } \\
\text { variables }\end{array}$} & central & $\begin{array}{l}\text { Central China }=1 \text {; other } \\
\text { areas }=0\end{array}$ & 0.43 & 0.50 & 0 & 1 & 5450 \\
\hline & west & $\begin{array}{l}\text { Western China }=1 \text {; other } \\
\text { areas }=0\end{array}$ & 0.21 & 0.41 & 0 & 1 & 5450 \\
\hline
\end{tabular}


We selected 11 factors as control variables in our models. Most of the householders bear the role of the household decision maker, and their ability to be engaged in migrant work is limited to their education level, which also affects the decision-making around household production. Marital status was selected as a factor in our study. According to Yin and Tian (2016), marital status has a significant impact on the land transfer decision, as unmarried people tend to become migrant workers, and married people prefer to farm at home. Because there is an age limit for non-agricultural employment, the average age of household laborers will significantly affect non-agricultural employment. As village cadres are more likely to know about the land transfer policy, they may be more inclined than others to transfer land. Whether the households have participated in the Grain for Green Project and whether the households have experienced land requisition can directly affect the farmland area, and these factors also indirectly affect the degree of dependence on agriculture. Whether the households have joined the agricultural cooperative economic organization can reflect the farmers' desire to obtain agricultural technical support. The per capita area of farmland reflects the household's land resource endowment, and it is a lateral reflection of the degree of fragmentation of cultivated land, which has an impact on rural land circulation (Latruffe and Piet, 2013). We also take landform conditions into consideration because the difficulty of land transfer is different in plain and mountainous areas. The per capita GDP (Gross Domestic Product) of each province was introduced to clarify the different land transfer behaviors in provinces with different economic development levels. Similarly, regional dummy variables were introduced to control regional differences in land transfer between the Eastern, Central and Western regions of China.

Table 2 shows the land transfer rate and farmers' non-agricultural employment in different provinces. There is a synchronous change between the land transfer-out rate and transfer-in rate in most sample provinces. According to the regional difference, the land transfer-in rates are high in Guangdong, Hunan, Anhui, Shandong and Hubei provinces, while they are relatively low in Henan, Beijing, Yunnan, Gansu and Shanxi provinces. The land transfer-out rate has an obvious regional difference in that it is high in Beijing, Jiangsu, Anhui, Guangdong and Sichuan provinces, while the transfer-out rates in Gansu, Liaoning, Shandong, Yunnan and Henan provinces are relatively low. In combination with non-agricultural employment, we noticed that the top five provinces with a high land transfer-out rate all have relatively high proportions of non-agricultural income, non-agricultural laborers and non-agricultural fixed operating assets. The situation is mirrored in the provinces with a low land transfer-out rate: their non-agricultural employment level is also low. Considering regional differences, there is a robust linear relationship between the proportion of non-agricultural laborers and the land transfer-out rate in the Central region of China. For the proportion of non-agricultural fixed operating assets, there is an approximate correlation with the transfer-out rate at the national level. From the correlation statistics, non-agricultural employment seems to influence land transfer-out behaviors to some extent.

According to the previous analysis, households with more involvement in non-agricultural industries may be more inclined to transfer out farmland, whereas households with more involvement in agricultural industries tend to transfer in more farmland. We define households whose non-agricultural income (agricultural income) accounts for more than $50 \%$ of the total household income as a non-agricultural income-based household (agricul- 
Table 2 Land transfer rate and farmers' non-agricultural employment in different provinces in 2013 (\%)

\begin{tabular}{llccccc}
\hline & \multicolumn{1}{c}{ Province } & Beijing & Liaoning & Jiangsu & Shandong & Guangdong \\
\hline Eastern & Land transfer-out rate & 27.88 & 3.19 & 21.24 & 5.43 & 14.51 \\
& Land transfer-in rate & 9.85 & 20.74 & 14.93 & 29.23 & 55.21 \\
& Proportion of non-agricultural income & 66.25 & 47.82 & 73.23 & 58.99 & 77.41 \\
& Proportion of non-agricultural laborers & 22.74 & 14.58 & 17.07 & 16.92 & 22.49 \\
& Proportion of non-agricultural fixed & 47.32 & 42.01 & 47.57 & 43.77 & 48.94 \\
& operating assets & & & & & \\
Central & Province & Shanxi & Anhui & Henan & Hubei & Hunan \\
China & Land transfer-out rate & 10.55 & 17.17 & 6.14 & 6.79 & 9.11 \\
& Land transfer-in rate & 29.86 & 9.21 & 25.07 & 31.28 \\
& Proportion of non-agricultural income & 52.07 & 59.20 & 65.79 & 56.63 & 70.54 \\
& Proportion of non-agricultural laborers & 19.93 & 32.43 & 22.08 & 28.34 & 28.47 \\
& Proportion of non-agricultural fixed & 48.24 & 44.32 & 44.38 & 44.33 & 45.61 \\
& operating assets & & & & & - \\
Western & Province & Sichuan & Chongqing & Yunnan & Gansu & - \\
& Land transfer-out rate & 13.41 & 7.34 & 5.67 & 1.65 & - \\
& Land transfer-in rate & 10.97 & 13.81 & 10.02 & 10.06 & - \\
& Proportion of non-agricultural income & 67.81 & 72.91 & 58.49 & 59.18 & - \\
& Proportion of non-agricultural laborers & 22.12 & 25.00 & 16.93 & 23.09 & - \\
& Proportion of non-agricultural fixed & 43.34 & 44.33 & 44.67 & 39.11 & - \\
& operating assets & & & & & \\
\hline
\end{tabular}

tural income-based household); those whose non-agricultural labor (agricultural labor) accounts for more than $50 \%$ of the total household labor force as a non-agricultural labor-predominant household (agricultural labor-predominant household); and those whose non-agricultural assets (agricultural assets) account for more than $50 \%$ of the total household assets as a non-agricultural assets-predominant household (agricultural assets-predominant household). The relationship between the land transfer rate and the degree of family non-agricultural employment in each province is shown in Figures 4 and 5. The results show that at present, the proportion of non-agricultural household income has reached a high level. Except for Liaoning, more than half of the sample households in other provinces are non-agricultural income-based households, and more than $70 \%$ of households in Guangdong, Chongqing and Sichuan are supported mainly by non-agricultural income. The provinces with more agricultural income-based households have relatively high land transfer-in rates, especially in Western China. Families with non-agricultural assets as their main assets have relatively high land transfer-out rates, especially in Western and Eastern China. Whether the family non-agricultural labor force is dominant does not well explain the spatial distribution of the land transfer rate.

\section{Results}

Non-agricultural employment affects households' land transfer-out decisions, as expected. We conducted the empirical analysis using a logit model to estimate the impact of farmers' non-agricultural income on land transfer-out and land transfer-in behaviors. The selection of independent variables involved comprehensive aspects to avoid omitted variable bias. 


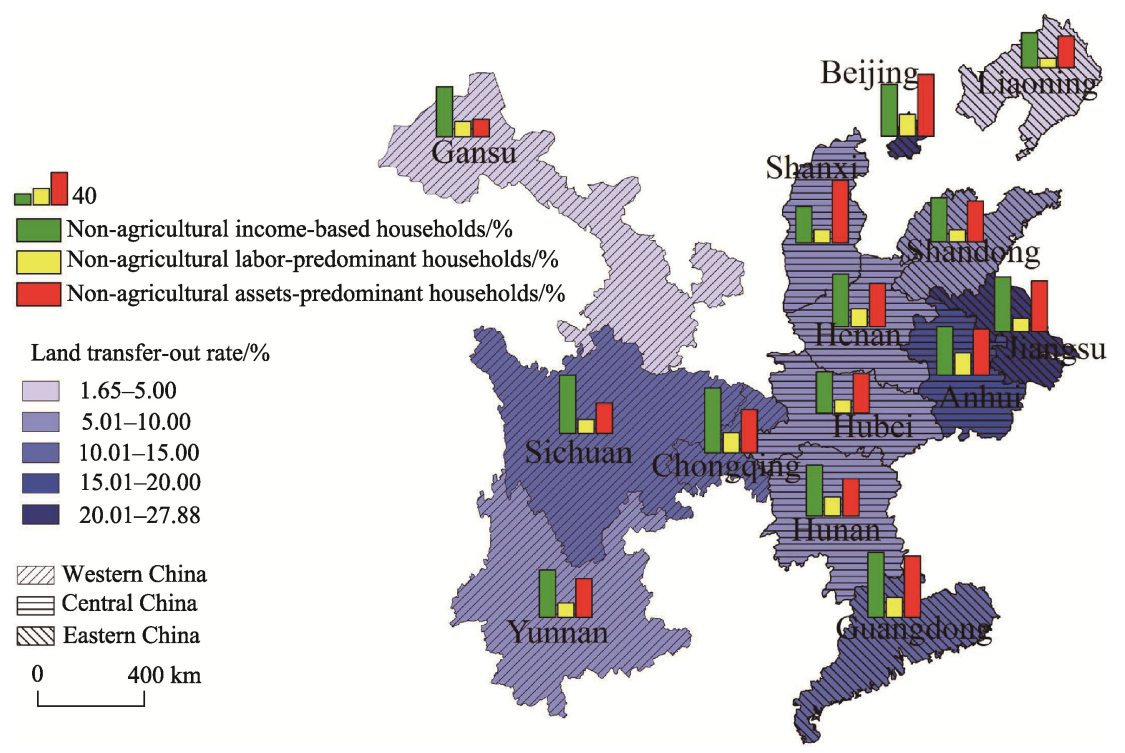

Figure 4 Non-agricultural employment characteristics and land transfer-out rate of farmer households (Total sample size $=5450$ )

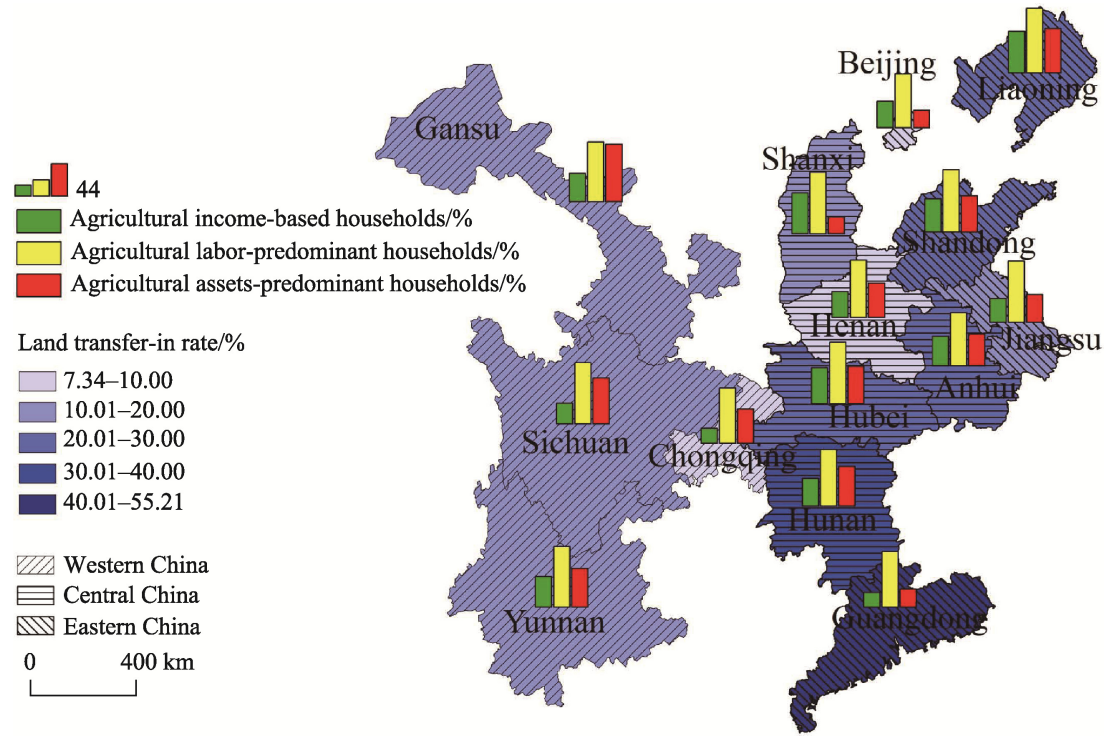

Figure 5 Agricultural employment characteristics and land transfer-in rate of farmer households (Total sample size $=5450$ )

Furthermore, all variables passed the multiple collinear tests; thus, there is no serious multicollinearity problem between variables. The statistical analyses were conducted using STATA 13.0

\subsection{Analysis of the impact of non-agricultural income on households' land trans- fer-out behaviors}

To test the suitability and accuracy of the model, we used the likelihood ratio index McFadden's $\mathrm{R}^{2}$ and AUC (area under curve) index. The higher the McFadden's $\mathrm{R}^{2}$ and AUC index, the better the goodness-of-fit. The McFadden's $\mathrm{R}^{2}$ index of the models below are all greater 
than $11 \%$, and the AUC are all greater than 0.73 , which indicates that the premise of the model is reasonable, and its results are believable. We also complete the robustness tests by adding and removing variables to confirm whether the impact direction and significance are stable. We eliminate various factors of householders' and households' characteristics in model 2 and compare the results with model 1. The results of the robustness test show that the four modeling results are identical; the logit model has high feasibility for land transfer-out decision modeling. Models east, central, and west are the results for the samples in Eastern, Central and Western China, respectively. The modeling results are summarized in Table 3.

For the non-agricultural employment factors, the proportion of non-agricultural income and the proportion of non-agricultural fixed operating assets have a significant positive impact on the farmers' land transfer-out decision at the $1 \%$ significance level, and the proportion of non-agricultural laborers is significant at the $15 \%$ level. As posited in our theoretical analysis, households with a larger proportion of non-agricultural income were disposed to transfer out their farmland. Agricultural income occupied only a small fraction of the total household income and was not sufficient to offset household expenses. This phenomenon caused a decline in the importance of farmland and an increase in the attractiveness of non-agricultural employment. The non-agricultural fixed operating assets reflected farmers' investment in non-agricultural industry; the higher the proportion of non-agricultural fixed operating assets was, the lower the proportion of agricultural fixed operating assets, and the lower the degree of attention to agriculture. The proportion of non-agricultural laborers is not as significant as expected but has indirect effects on the land transfer-out decision. The definition of non-agricultural laborers is based on whether an individual migrated for work in 2013. As there are short-term and long-term migrant workers, the migratory household members may change roles; thus, there is uncertainty in the results from these data. From the perspective of regional differences, because of the high level of non-agricultural income in Eastern China, the land transfer-out rate in the Eastern region is mainly affected by the proportion of non-agricultural labor and non-agricultural assets. Of these, the influence of the proportion of non-agricultural labor is negative, which may be due to the small per capita arable land area in the Eastern region and the limited number of laborers needed to manage their contracted farmland.

For the factors concerning householder characteristics, education level has a significant positive effect on the land transfer-out decision, especially in Eastern and Western China. Householders with a higher education level are more willing to make the decision to transfer out their land. Marital status has no obvious impact on the land transfer-out decision, which is different from the result of Yin and Tian (2016).

For the households' characteristics, the average age of household laborers has a significant positive effect on the land transfer-out decision. The higher the laborers' average age, the greater the likelihood of transferring out land. Combined with our statistical description, the average age of household laborers is 47.96 years old in the households that have transferred out their land, and 45.48 years old in the households that have not transferred out their land. The laborers who are slightly older than 45.48 belong to a group with social experience and working ability, and they are more willing to be engaged in the non-agricultural industry to support their family. If the households participated in the Grain for Green Project, their 


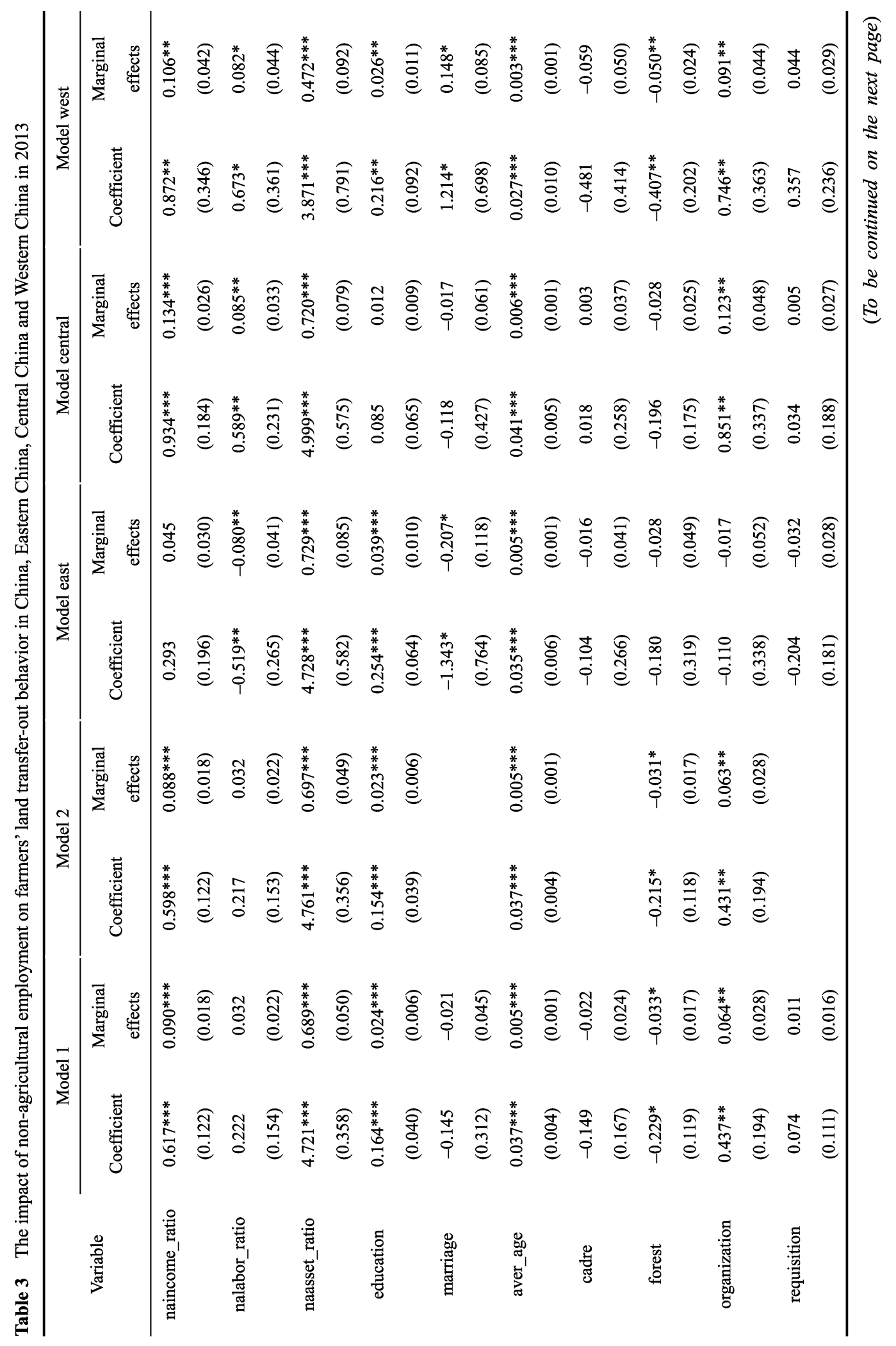




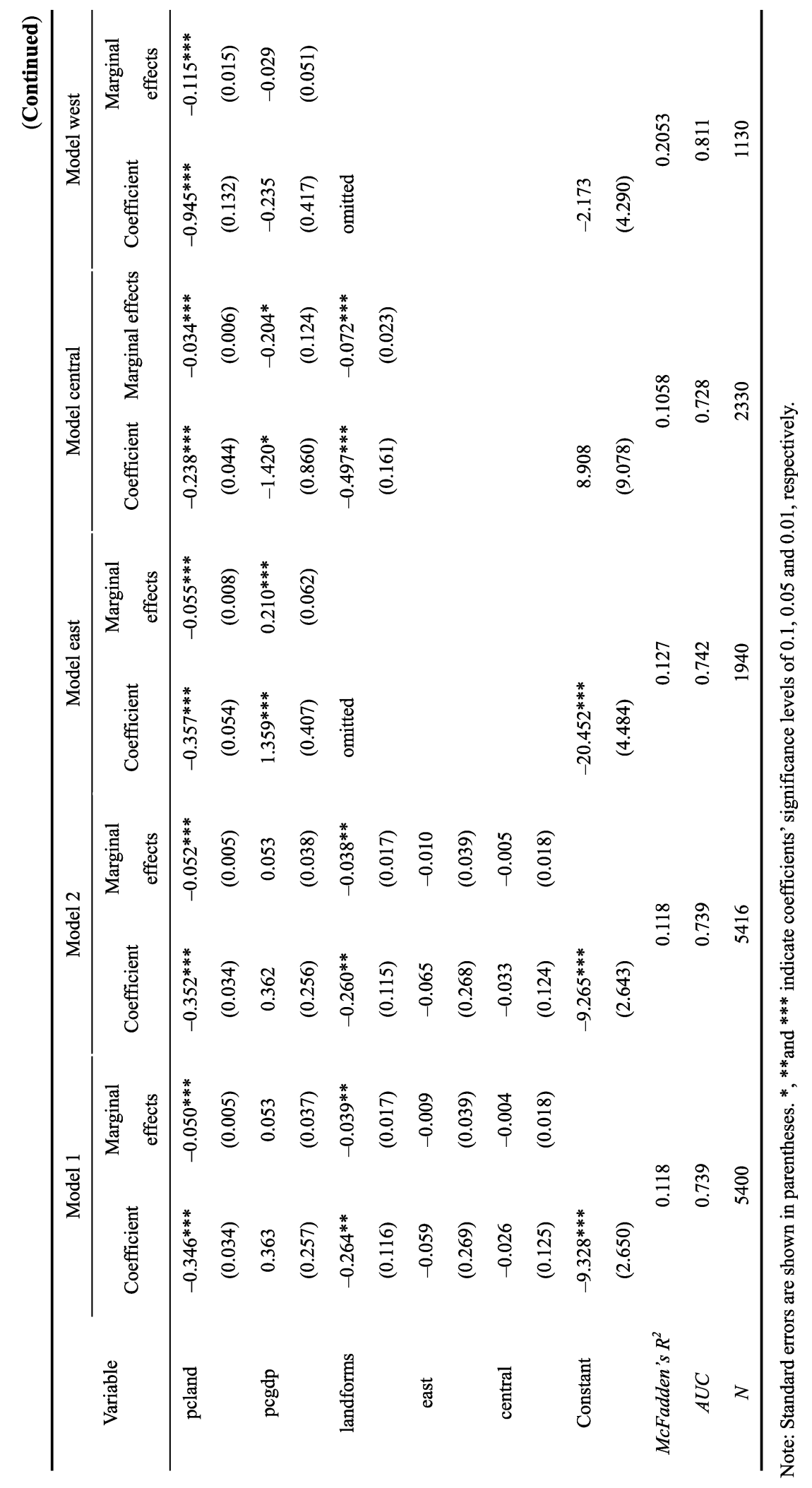


household's farmland has already been reduced so they no longer expect to continue reducing farmland by transferring it out, especially in Western China. According to our field research, elderly people tend to farm for their own household's grain ratio; thus, they are not willing to transfer out their farmland.

For the land management factors, the per capita area of farmland has a significant negative effect on the land transfer-out decision. If the per capita area of farmland is small, the household is less dependent on agriculture, and the farmland is simultaneously more likely to be fragmented, which has stunted farmland cultivation (Tan et al., 2008). This result leads to a low possibility of transferring out land to others. In Western China in particular, for every unit increase in per capita area of farmland, the probability of farmers choosing to transfer-out land decreased by 0.12 .

For the landform condition factors, land transfer out is more likely to occur in the mountainous region. Poor farming conditions in mountainous areas cause high investment in agriculture and low efficiency of agricultural output. The comparative effectiveness is low for agricultural production compared with the non-agricultural industry, so farmers want to transfer out their land.

The probability of farmers choosing to transfer out land increases by 0.09 with a one-unit increase in the proportion of non-agricultural income. In terms of regional differences, in the Central region, the probability increases by 0.13 and in the Western region, by 0.11 . The increase in the probability is higher in Central China than in Western China; in the Eastern region, there is no significant influence, mainly because non-agricultural income in the Eastern region has already reached a high level. The change in the proportion of non-agricultural labor has no significant impact on the decision to transfer out land when looking at China as a whole, while in Central and Western China, it has a positive impact, with this impact being higher in Central China than in Western China. In Eastern China, it has a negative impact, which is most likely because the per capita farmland in the Eastern region is relatively small, leaving surplus labor in the family so that the transfer of the labor force has no positive impact on the decision to transfer out farmland. For every unit increase in the proportion of non-agricultural assets, the probability of farmers choosing to transfer out land increases by 0.69 across China as a whole, by 0.73 in the Eastern region, 0.72 in the Central region and 0.47 in the Western region. The order of this impact in different regions is Eastern China $>$ Central China $>$ Western China; because non-agricultural assets in the Western region are still at a low level, the decision to transfer out land is not sensitive to the change in the proportion of non-agricultural assets. The proportion of non-agricultural assets in the west is still at a low level, so the sensitivity of land transfer decision-making to a change in non-agricultural assets is still low. The above results are consistent with the two main contentions that we mentioned in section 2.1 of this paper.

\subsection{Analysis of the impact of non-agricultural income on households' land transfer-in behaviors}

The modeling of farmers' land transfer-in behavior is also a type of robustness test. If the households that treat agricultural income as the main source of household income tend to rent more farmland to increase their revenues, this also confirms the robustness of the above model, which says that a household engaged in non-agricultural work is not willing to culti- 


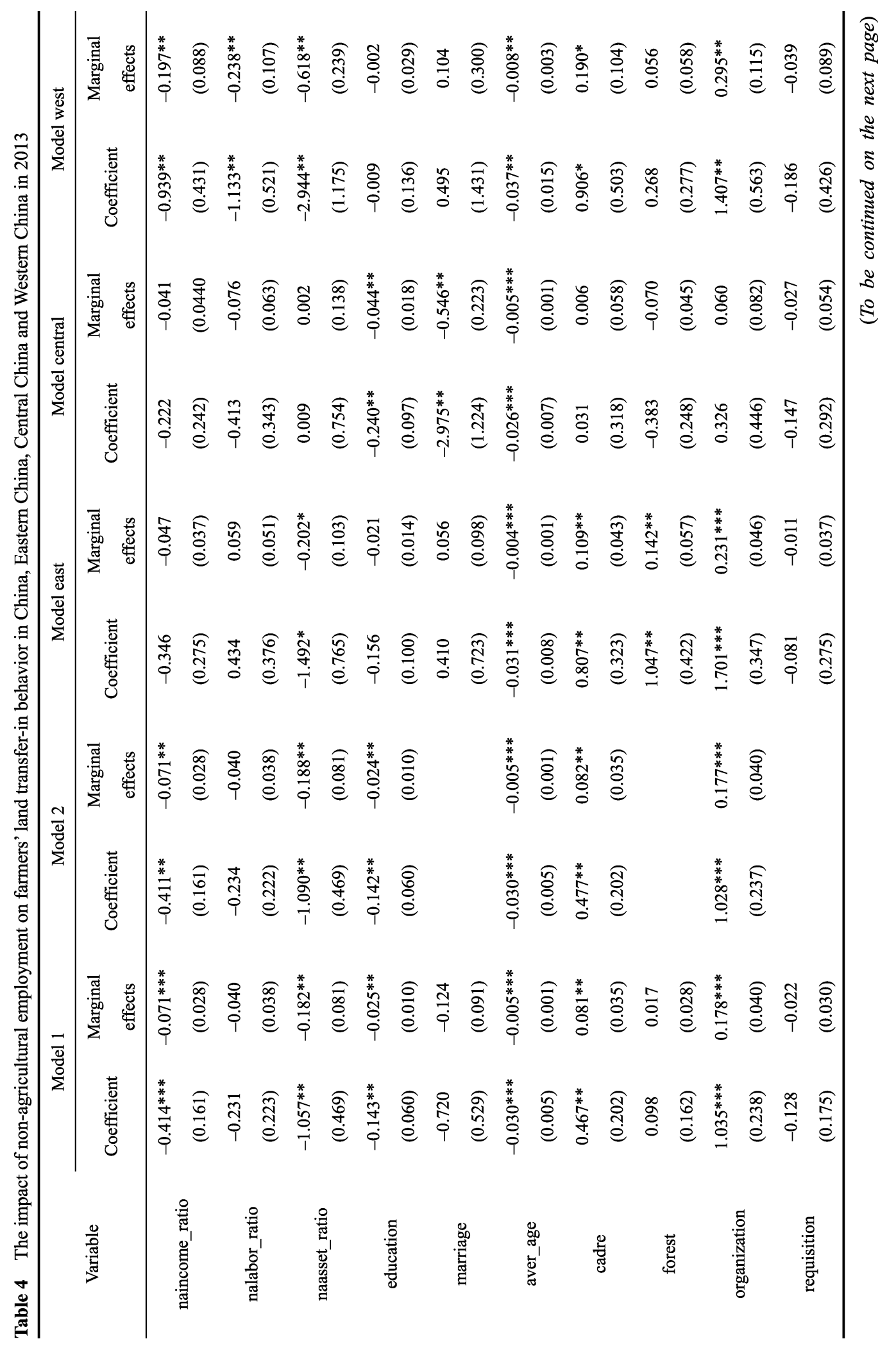




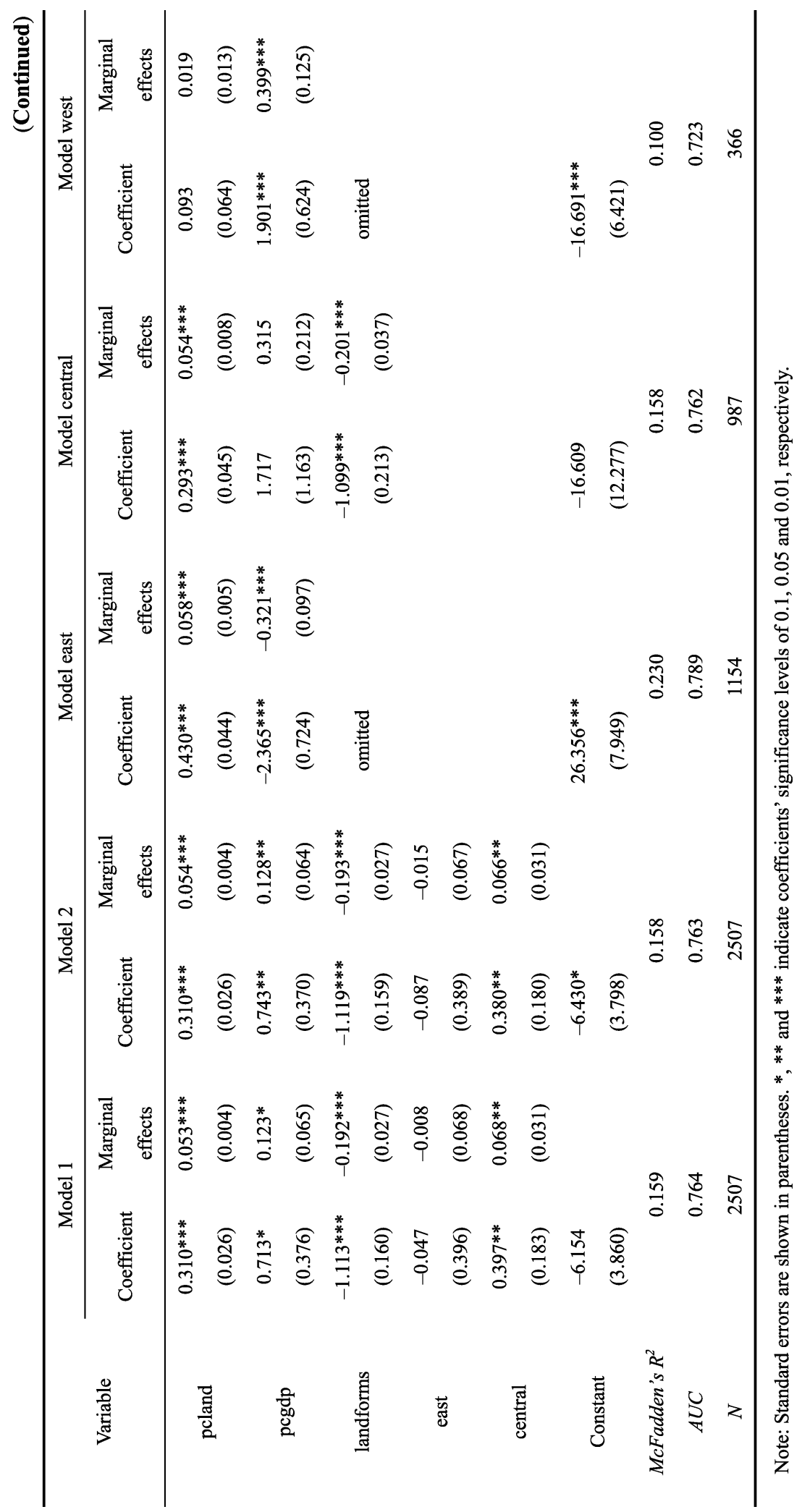


vate more farmland. We again used the likelihood ratio index McFadden's $\mathrm{R}^{2}$ and the AUC index to test the suitability and accuracy of the model. The McFadden's $\mathrm{R}^{2}$ index of the models below are all greater than $15 \%$, and the AUC are all greater than 0.75 , which indicates that the goodness-of-fit is high and the results are convincing. We also complete the robust test by adding and removing variables, and the results show that the modeling results are robust; the logit model has high feasibility for land transfer-in decision modeling. We also create three other models using the samples in the Eastern, Central and Western regions. The modeling results are summarized in Table 4.

For the non-agricultural employment factors, the proportion of non-agricultural income and proportion of non-agricultural fixed operating assets have significant negative impacts on farmers' land transfer-in decision, while the proportion of non-agricultural laborers has no obvious impact. There is a negative relationship between non-agricultural employment and farmers' land transfer-in decision. A higher proportion of non-agricultural income indicates less dependence on land and a lower willingness to expand the current scale of farmland. A higher proportion of non-agricultural fixed operating assets reflects lower inputs, attention to agriculture, and willingness to be engaged in agricultural activities. Examining regional differences, in the Eastern region, the proportion of non-agricultural assets has a significant negative impact on the land transfer-in rate. The three selected non-agricultural employment characteristics have no significant impact on the land transfer-in rate in the Central region. In the Western region, the three characteristics of non-agricultural employment have a significant negative impact on the land transfer-in rate.

For the householders' characteristics, education level has a significant negative effect on the land transfer-in decision, especially in Central China. Because there are some restrictions on the education level for migrant workers, householders with a lower education level are more likely to farm at home; they are thus more willing to make the decision to transfer in land.

Considering households' characteristics, the average age of household laborers has a significant negative effect on the land transfer-in decision. The higher the laborers' average age is, the lower the likelihood they will transfer in land. Combined with our statistical description, in households that have transferred in more land, the average age of household laborers is 44.48 years old, and in households that have not transferred in land, the laborers' average age is 46.20 years old. As we stated above, laborers slightly older than 46.20 are more willing to be engaged in non-agricultural industries. Elderly people are not willing to cultivate their land, let alone to transfer in more land. Additionally, having a village cadre in the household means that household is more likely to learn of land management policies and gain other timely knowledge, so these households tend to transfer in more farmland to maintain their stable life, especially in Eastern and Western China. In addition, if a household has joined the agricultural cooperative economic organization, it tends to have greater enthusiasm for agriculture and to learn more farming techniques and skills from the organization; thus, it is more likely that they will transfer in more land, especially in Eastern and Western China. We also found that, combined with the land transfer-out models, households that have joined an agricultural cooperative economic organization are more likely to both transfer in and transfer out land, which may be because this group of farmers is more enthusiastic about operating and adjusting their land; they adjust their land by transferring in and transferring out land to create better conditions for scale cultivation. 
Considering the land management factors, the per capita area of farmland has a significant positive effect on the land transfer-in decision, especially in Eastern and Central China. If the per capita area of farmland is high, the household is more dependent on agriculture, the average area of the land parcel is larger, and the quality is higher, which leads to a high possibility of transferring land.

Looking at the different economic levels in different provinces, per capita GDP has a significant positive effect on the land transfer-in decision. The higher the region's level of economic development is, the more likely that farmers will transfer in more land, especially in Western China. Similarly, the regional dummy variable representing the Central region of China shows that the number of households that have transferred in farmland is much greater than it is in the Western region of China. For the Eastern region, because the overall level of economic development is higher, as the level of economic development increases, farmers become less likely to transfer in more land.

For the landform condition factors, land transfer in is more likely to occur in mountainous regions. In the analysis of the land transfer-out models above, we found that rural land circulation in mountainous areas is more frequent and common than that in the plains. The agricultural production conditions are poor in mountainous areas; therefore, farmers transfer land to concentrate on flat land and improve production conditions, or they even transfer out their land and migrate to gain greater benefits from non-agricultural industry.

When the proportion of non-agricultural income increases by one unit, the probability of farmers' deciding to transfer-in land decreases by 0.07 . The increase in the non-agricultural income ratio has a stronger effect on the transfer-out decision than it does on the transfer-out decision. In terms of regional differences, there is no significant impact in the Eastern and Central regions, while the probability of decision to transfer in land decreases by 0.20 in the Western region. The probability that a household will transfer in land in the Western region will decrease by 0.24 with a one-unit increase in the proportion of non-agricultural labor. For every unit increase in the proportion of non-agricultural assets, the probability that farmers transfer in land will decrease by 0.18 in all of China, 0.20 in the Eastern region and 0.62 in the Western region. The above results further verify the validity of the two main contentions that we discussed in section 2.1 of this paper.

\section{Discussion and conclusions}

\subsection{Discussion}

There is always debate whether an increase in non-agricultural income will promote or reduce farmers' investment in agriculture, but a reduction is more likely according to this study. From the perspective of the cost and benefit of agricultural production, the profits from agriculture are steadily decreasing. Figure 6 shows the changes in costs and benefits for the three major grain crops (rice, wheat and corn) during the period of 2005-2013. The investment in grain production per mu increased yearly and at an increasing rate, while at the same time, the net profit per mu has decreased significantly since 2011. If farmers are engaged in non-agricultural work, there will be no investment expenditure, and more net revenue will be earned per laborer. These changes have lowered the status of agriculture in farmers' minds; they no longer treat agricultural work as the best means of subsistence, and 
they transfer out farmland naturally.

Because of the slow increase in agricultural income, the attractiveness of agriculture to farmers is less than that of becoming a migrant worker. Households with higher labor opportunity costs are more likely to reduce labor intensity and increase labor-saving inputs in their land use decisions (Chen, 2010). One study shows that nonfarm income has a significant effect on reducing the supply of family labor to the farm in Mexico (Pfeiffer et al., 2010). Figure 7 shows that the rural households' average per capita income, average per capita agricultural net income and average per capita consumption expenditure tended to increase over the period of 1995-2012. The rate of increase in per capita income is quite consistent with that of per capita consumption expenditure. However, the fluctuation in agricultural income is larger, and its rate of increase is lower than that of income in recent years. Per capita income is higher than per capita agricultural income, especially after 2005 . Income is greater than agricultural income and has a tendency to represent the main source of household

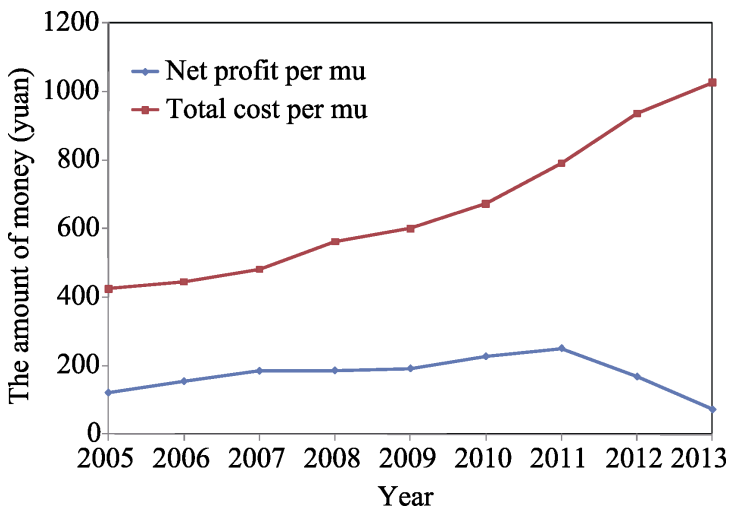

Figure 6 Changes in average net profit and average input cost for three types of grain from 2005 to 2013 (Data source: National Development and Reform Commission)

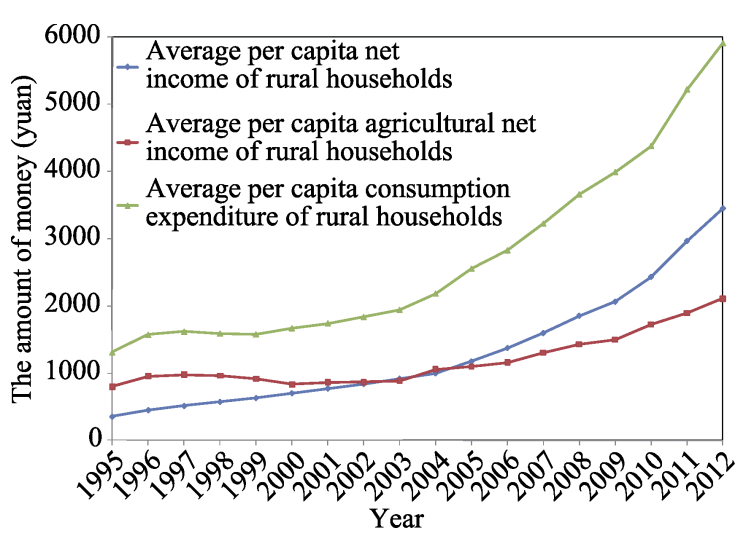

Figure 7 Changes in rural residents' household income during the period 1995-2012 (Data sources: National Bureau of Statistics) income as households' consumption levels continue to increase. A significantly negative relationship between nonfarm income and per capita farm income was also found in Ghana (Egyei et al., 2013). In addition, a reduction in farm inputs used was found when access to nonfarm employment improved in Ethiopia (Holden et al., 2004). These factors directly cause a decline in the importance of farmland and prompt more farmers to reduce their inputs to agriculture and to decide to transfer out their land.

\subsection{Conclusions}

Using the CHIP2013 dataset, we focused on the impact of farmers' non-agricultural employment on rural land circulation in China. Including the comprehensive consideration of possible influencing factors, the logit model results showed that the proportion of non-agricultural assets has the greatest impact on the decision-making around land transfer, followed by the proportion of non-agricultural income. An increase in the non-agricultural income ratio has a stronger effect on the transfer-out than on the transfer-in decision. In terms of regional differences, for the Eastern region, the decision to transfer out land is 
mainly affected by the proportion of non-agricultural assets and of the non-agricultural labor force, and the decision to transfer in land is mainly affected by the proportion of non-agricultural assets. In the Central and Western regions, the decision to transfer out land is mainly affected by the proportion of non-agricultural assets, non-agricultural income and the non-agricultural labor force, in that order. The decision to transfer in land in the Central region is not significantly affected by non-agricultural employment. The decision to transfer in land in the Western region is mainly affected by the proportion of non-agricultural assets, the non-agricultural labor force and non-agricultural income, in that order.

Householders' education level and laborers' average age play an important role in rural land circulation in that they have a significantly positive relationship with the transfer out and a negative relationship with the transfer in of farmland. Knowledge and technical training for farmers may be an effective means of promoting non-agricultural employment while facilitating rural land circulation. Additionally, we found that there is frequent rural land circulation in mountainous areas, as farmers adjust their farming conditions by transferring farmland in and out.

Moderate scale management has become a current trend in agricultural management; attention should be paid to the impact of non-agricultural employment on rural land circulation, and decision makers should be aware that the increasing importance of non-agricultural income is the basis for farmers' land transfer-out decisions. Land transfer in the Central and Western regions still needs to be further promoted. It is noted that the decision-making around land transfer in the Central and Western regions is affected by a change in the proportion of non-agricultural labor, and development of the labor market in the Central and Western regions should be considered. The farmers' labor market should be perfected to promote rural land circulation. While paying attention to the influence of non-agricultural income on the decision around land transfer, we should also pay attention to the influence of non-agricultural assets; it can be seen that the stability of non-agricultural employment is important in promoting land transfer. The more non-agricultural assets farmers accumulate, the more stable their engagement in non-agricultural work will be. Therefore, we should speed up the construction of the labor market, increase vocational skills training, improve the rights and interests of migrant workers, and subsidize the purchase of agricultural machinery for those farmers who want to transfer in farmland to ensure the stability of farmers' non-agricultural employment and promote orderly land transfer. However, we should pay attention to the regional differences in rural land circulation and to rural land circulation in the mountainous areas and promote greater circulation in the plain areas to form large-scale operations. Further research should be conducted to find suitable regions for large-scale operations in the plain areas, and measures should be taken to adjust the employment structure to absorb more of the rural labor force in cities and promote moderate scale management in rural areas. This study provides a theoretical reference for policies affecting agricultural and migrant workers in China.

\section{References}

Bao Z S, Xu Z M, Gao S et al., 2009. Regional differences of land circulation and driving forces: A case study of Jiangsu Province. Chinese Rural Economy, (4): 23-47. (in Chinese)

Cassidy A, Mcgrath B, 2015. Farm, place and identity construction among Irish farm youth who migrate. Journal of Rural Studies, 37: 20-28. 
Che Y, 2014. Mismatch: Land reallocations, recovery land rental and land rental market development in rural China. China Agricultural Economic Review, 6(2): 229-247(219). (in Chinese)

Chen H L, Shi Q H, Gu H Y, 2014. Is land circulation efficient? A case study of Shanxi Province. Chinese Rural Economy, (7): 61-71. (in Chinese)

Chen Y Q, 2010. Agricultural land use responses to the rising labor opportunity cost in Sui county, China. Chinese Journal of Population, Resources and Environment, 8(4): 10-18. (in Chinese)

Chen Y Q, Li X B, Zhu H Y et al., 2010. Agricultural land use responses to increasing labor opportunity cost in Suixian county of Henan province. Progress in Geography, 29(9): 1067-1074. (in Chinese)

Choi Y J, 2001. Rural labor flows in China (review). China Review International, 8(2): 578-580.

Deininger K, Jin S, 2005. The potential of land rental markets in the process of economic development: Evidence from China. Journal of Development Economics, 78(1): 241-270.

Deininger K, Jin S, Berhanu A et al., 2001. Mechanisms for land transfer in Ethiopia: Implications for efficiency, equity and non-farm development. Ethiopian Journal of Economics, 10: 21-54.

Ellis F, 2006. Peasant Economics: Peasant Household Agricultural and Agriculture Development. Shanghai: Shanghai People's Publishing House.

Egyei R K, Harrison P, Adzovor Y, 2013. Household non-farm income: Any influence on agricultural productivity in rural Ghana? Developing Country Studies, 3(9): 79-91.

Feng S, 2008. Land rental, off-farm employment and technical efficiency of farm households in Jiangxi Province, China. NJAS-Wageningen Journal of Life Sciences, 55(4): 363-378.

Feng S, Heerink N, Ruben R et al., 2010. Land rental market, off-farm employment and agricultural production in Southeast China: A plot-level case study. China Economic Review, 21(4): 598-606.

Gao L L, Huang J K, 2011. The relationship between different types of circulated agricultural land and household investment. Chinese Rural Economy, (4): 9-17. (in Chinese)

Han H, Zhong F N, 2011. The impacts of remained land after labor outflow on local farmers's income distribution. Chinese Rural Economy, (4): 18-25. (in Chinese)

Hao H G, Li X B, Xin L J, 2017. Impacts of non-farm employment of rural laborers on agricultural land use: Theoretical analysis and its policy implications. Journal of Resources and Ecology, 8(6): 595-604.

Holden S, Shiferaw B, Pender J, 2004. Non-farm income, household welfare, and sustainable land management in a less-favoured area in the Ethiopian highlands. Food Policy, 29(4): 369-392.

Huang J, Gao L, Rozelle S, 2012. The effect of off-farm employment on the decisions of households to rent out and rent in cultivated land in China. China Agricultural Economic Review, 4(1): 5-17.

Huang J, Wu Y, Rozelle S, 2009. Moving off the farm and intensifying agricultural production in Shandong: A case study of rural labor market linkages in China. Agricultural Economics, 40(2): 203-218.

Huang Z H, Wang P, 2008. Farmland transfer and its impacts on the development of modern agriculture: Status, problems and solutions. Journal of Zhejiang University (Humanities and Social Sciences), 38(2): 38-47. (in Chinese)

Huy H T, Lyne M, Ratna N et al., 2016. Drivers of transaction costs affecting participation in the rental market for cropland in Vietnam. Australian Journal of Agricultural \& Resource Economics, 60(3): 476-492.

Jia Q Y, 2012. A study on the relationship between Chinese rural land transfer and non-farm income [D]. Jinan: Shandong University of Finance and Economics. (in Chinese)

Kawasaki K, 2010. The costs and benefits of land fragmentation of rice farms in Japan. Australian Journal of Agricultural \& Resource Economics, 54(4): 509-526.

Kawasaki K, 2011. The impact of land fragmentation on rice production cost and input use. Japanese Journal of Rural Economics, 13: 1-14.

Kung J K S, Lee Y F, 2001. So what if there is income inequality? The distributive consequence of nonfarm employment in rural China. Economic Development \& Cultural Change, 50(1): 19-46.

Low A, 1986. Agricultural Development in Southern Africa: Farm Household Economics and the Food Crisis. London: James Currey.

Latruffe L, Piet L, 2013. Does land fragmentation affect farm performance? Agricultural Systems, 129: 68-80.

Lin J Y, 1992. Rural reforms and agricultural growth in China. American Economic Review, 82(1): 34-51.

Liu T, Qu F T, Jin J et al., 2008. Impact of land fragmentation and land transfer on farmer's land use efficiency. Resources Science, 30(10): 1511-1516. (in Chinese)

Liu Y X, Xu H Z, 2016. Influence of farmland right to rural land circulation: Based on the perspective of farmers differentiation. Journal of Arid Land Resources and Environment, 30(5): 25-29. (in Chinese) 
Ma X L, Qiu T W, Qian Z H, 2015. Farmland property and land market participation of rural households: An Empirical Analysis of Jiangsu, Hubei, Guangxi and Heilongjiang provinces, China. Chinese Rural Economy, (2): 22-37. (in Chinese)

Manjunatha A V, Anik A R, Speelman S et al., 2013. Impact of land fragmentation, farm size, land ownership and crop diversity on profit and efficiency of irrigated farms in India. Land Use Policy, 31: 397-405.

National Bureau of Statistics (NBS), 1996-2013. China Statistical Yearbook. Beijing: China Statistics Press. (in Chinese)

National Development and Reform Commission (NDRC), 2006-2014. Compilation of Cost-Benefit Data of National Agricultural Products. Beijing: China Statistics Press. (in Chinese)

Niroula G S, Thapa G B, 2007. Impacts of land fragmentation on input use, crop yield and production efficiency in the mountains of Nepal. Land Degradation \& Development, 18(3): 237-248.

Office for Fixed Rural Observation Villages (OFROV) of Policy Research Department of Central Committee of the Chinese Communist Party and Ministry of Agriculture, 2001. National Rural Social-economic Survey Data Collection, 1986-1999. Beijing: China Agricultural Publishing House. (in Chinese)

Office for Fixed Rural Observation Villages of Policy Research Department of Central Committee of the Chinese Communist Party and Ministry of Agriculture, 2010. National Fixed Rural Observation Villages Data Compilation, 2000-2009. Beijing: China Agricultural Publishing House. (in Chinese)

Penov I, 2004. The use of irrigation water in Bulgaria's Plovdiv region during transition. Environmental Management, 34(2): 304-313.

Pfeiffer L, Lopez-Feldman A, Taylor J E, 2010. Is off-farm income reforming the farm? Evidence from Mexico. Agricultural Economics, 40(2): 125-138.

Pilgaard S B, Birch T, 2013. Should I stay or should I go? Rural youth employment in Uganda and Zambia. International Development Planning Review, 35(2): 175-201.

Qian Z H, Mou Y, 2012. Regional difference of land marketization in China. Jiangsu Social Sciences, (4): $45-53$. (in Chinese)

Singh I, Squire L, Strauss J, 1986. Agricultural Household Models: Extensions, Applications, and Policy. Johns Hopkins University Press.

Tan M H, Guy M R, Li X B et al., 2013. Spatial and temporal variability of farm size in China in context of rapid urbanization. Chinese Geographical Science, 23(5): 607-619.

Tan S, Heerink N, Kruseman G et al., 2008. Do fragmented landholdings have higher production costs? Evidence from rice farmers in northeastern Jiangxi province, P.R. China. China Economic Review, 19(3): 347-358.

Tan S H, Qu F T, Heerink N, 2003. Causes of land fragmentation and driving forces. China Rural Survey, (6): 24-30. (in Chinese)

Tian Y J, Li X B, Xin L J et al., 2009. Impacts of the rise of labor opportunity cost on agricultural land use changes: A case study of Ningxia Hui Autonomous Region. Journal of Natural Resources, 24(3): 369-377. (in Chinese)

Todorova S A, Lulcheva D, 2006. Economic and social effects of land fragementation on Bulgarian agriculture. Journal of Central European Agriculture, 6(4): 555-562.

Wang C C, Yang Y S, 2011. Impact of rural households' nonfarm employment on cropland transfer: Case of Changting county in Fujian Province, China. Scientia Geographica Sinica, 31(11): 1362-1367. (in Chinese)

Xie H L, Lu H, 2017. Impact of land fragmentation and non-agricultural labor supply on circulation of agricultural land management rights. Land Use Policy, 68: 355-364.

$\mathrm{Xu} \mathrm{H} \mathrm{Z,} \mathrm{Guo} \mathrm{Y} \mathrm{Y,} \mathrm{2011.} \mathrm{Co-integration} \mathrm{test} \mathrm{and} \mathrm{causality} \mathrm{analysis} \mathrm{on} \mathrm{the} \mathrm{relationship} \mathrm{between} \mathrm{farmers'}$ Non-agricultural income and farmland transfer. China Population, Resources and Environment, 21(6): 61-66. (in Chinese)

Yan X, Huo X, 2016. Drivers of household entry and intensity in land rental market in rural China: Evidence from North Henan Province. China Agricultural Economic Review, 8(2): 345-364.

Yang Y, 2000. The development of the land lease market in rural China. Land Economics, 76(2): $252-266$.

Yin X H, Tian C H, 2016. The impact of land markets on farmers' income in China. China Real Estate, (5): 29-41. (in Chinese)

Zhang Z, Zhou H C, 2017. Off-farm employment, insurance selection and land transfer. China Land Sciences, 31(10): 42-52. (in Chinese)

Zhu H Y, Li X B, Xin L J, 2007. Intensity change in cultivated land use in China and its policy implications. Journal of Natural Resources, 22(6): 907-915. (in Chinese) 